\title{
Extraction, Chemical Composition, and Characterization of Potential Lignocellulosic Biomasses and Polymers from Corn Plant Parts
}

\author{
M.I.J. Ibrahim, ${ }^{\mathrm{a}, \mathrm{b}}$ S.M. Sapuan,,${ }^{\mathrm{a}, \mathrm{c},}$ E.S. Zainudin, ${ }^{\mathrm{a}}$ and M.Y.M. Zuhri ${ }^{\mathrm{a}}$ \\ Corn is a plant that can be used as a potential source of biomass for various \\ biomaterial applications. Thermoplastic corn starch and corn hull, husk, and \\ stalk fibers were extracted from different corn plant parts. The chemical \\ composition, physical properties, thermal stability, crystallinity index, and \\ surface morphology of the extracted samples were characterized on a \\ powder basis. The corn husk and corn starch revealed an excellent \\ combination of properties. Corn husk provided the highest cellulose content \\ as well as the most favorable surface morphology. Corn starch revealed \\ acceptable amylose content and tolerable thermal stability. The cellulose \\ and starch demonstrated an excellent correlation between the function and \\ structure of biomolecules. Hence, both corn starch and husk have potential \\ for use in many applications of the biomaterial.
}

Keywords: Corn biomasses; Chemical composition; Physical; Thermal; Morphological properties

Contact information: a: Advanced Engineering Materials And Composites Research Centre, Department of Mechanical and Manufacturing Engineering, Universiti Putra Malaysia, 43400 UPM Serdang, Selangor, Malaysia; b: Department of Mechanical and Manufacturing Engineering, Sabha University, Libya; c: Laboratory of Biocomposite Technology, Institute of Tropical Forestry and Forest Products (INTROP), Universiti Putra Malaysia, 43400 UPM Serdang, Selangor, Malaysia; *Corresponding author: sapuan@upm.edu.my

\section{INTRODUCTION}

Contemporary environmental concerns, such as non-biodegradable disposal materials, plant wastes, and rising mountains of garbage are increasingly documented as environmental barriers (Ibrahim et al. 2019). The area for landfills is limited, and further incineration capacities require high capital investment and cause additional environmental threats. These issues have prompted the design and manufacture of eco-friendly materials from renewable sources to replace conventional non-biodegradable materials. Reducing the dependence on synthetic plastic and petroleum products is one reason for investigating biomasses in reinforcing polymer composites (Mori et al. 2018). Furthermore, the use of biomasses as reinforcement in composites would lead to partial degradation of wastes, which in turn contributes to the solution of environmental complications.

Corn (maize) is one of the most abundant sources of plant residues, which as biomass provides multiple advantages such as high concentration of starch, excellent consistency, cost-effectiveness, availability, and biodegradability (Mendes et al. 2016). According to Sandhu et al. (2004), corn is among the most abundant agriculture cereals planted on earth. There are typically six common sorts of maize, namely dent, flint, pop, pod, flour, and sweet corn. These sorts vary remarkably in their physiochemical characteristics due to environmental influences. The production of corn in 2014 was estimated at 1.04 billion tons, which corresponded to $31 \%$ of the global cereal production; 
therefore, corn became the third most important food grain (Singh et al. 2016). The corn plant consists of one stem or more associated with a combination of short roots. The stem branches at each node and ends with inflorescences. After harvest, the corn parts are turned into residues that are disposed (Weatherwax 1950).

Corn is a vital source of commercial starch, which is a type alpha-linked glucose that is used extensively in food factories as a gelling, water retention, and bulking agent (Zobel 1988). More than 70\% of corn kernel composition is starch, and the rest is sugar, protein, oil, and ash. However, many natural fibers can be extracted from corn plant parts including the stalk, straw, leave, and husk. Compared with other agricultural bioproducts, corn fiber offers distinct features such as saving $90 \%$ of the cost and being more accessible than other natural fibers (McAloon et al. 2000).

The use of natural fibers as reinforcing materials in polymers and composites is a major area of research interest. The chemical composition, morphological structure, and thermal stability of biomass are essential criteria to select the best lignocellulosic material (Brinchi et al. 2013). To date, there is insufficient research on the applications of corn polymers, fibers, and composites, with no study conducted on the physical, morphological, and thermal properties of corn biomass. This study considers the physiochemical composition, thermal characteristics, and crystallinity index and morphological properties of corn biopolymers and biofibers with the aim of exploring their potential in the development of biocomposites.

\section{EXPERIMENTAL}

\section{Materials}

Corn was collected from a local farm in Malaysia. Corn starch and corn hull fiber were extracted from the granules of a fresh sweet corn ear. Corn stalk and husk were obtained from the stems and leaves of corn plants, respectively. All samples were characterized in a powder basis.

\section{Starch and Fiber Extraction Processes}

The isolation of corn starch was carried out in accordance with Ali et al. (2016). Corn grains $(1 \mathrm{~kg})$ were steeped in distilled water $(4 \mathrm{~L})$ for $12 \mathrm{~h}$ at $4{ }^{\circ} \mathrm{C}$. The purpose of the steeping is to increase grain moisture to facilitate grinding process. After the water was evacuated, the grains were crushed in a lab electric blender (wet milling) until the minimum likely fraction was achieved. The crushed fractions were sifted through a $75 \mu \mathrm{m}$ mesh sieve and then left to sediment for $8 \mathrm{~h}$. The supernatant liquid was discarded, and the sedimented particles were suspended in distilled water to remove any residual protein from the starch. The slurry of starch and water was separated by centrifugation at $3000 \mathrm{rpm}$ for $20 \mathrm{~min}$. The obtained corn starch was dehydrated at $50{ }^{\circ} \mathrm{C}$ for $12 \mathrm{~h}$ in an air circulation oven (type Venticell 22, Planegg, Germany); the dried corn starch was blended and sieved to achieve uniform particle size distribution.

Corn hull fiber was obtained via the wet milling process during starch isolation. The industrial production of corn starch involves the elimination of proteins and separation of fibers resulting in purified starch and solid residues called de-starched corn hull fiber which exists in corn grain pericarp. Subsequently, the remaining fiber was washed many times with hot distilled water to remove starch molecules and then was separated by centrifugation. Either by drying in an oven or direct sunray, the hull fiber was dehydrated 
and converted to powder form via grinding and sieving processes.

Corn husk fiber was obtained according to Sari et al. (2016). Husks surrounding the ear of corn were soaked in condensed water for 3 days to remove the residuals and dust. The husks were thoroughly washed by fresh water and brushed with a soft plastic comb. The husks were air-dried, ground, and screened through a sieve to be in powder form. The extraction of corn stalk fiber was performed as described by Baranitharan and Mahesh (2014). Raw corn stalks were cleaned thoroughly and chopped into specific sizes; they were completely dehydrated in an oven for $12 \mathrm{~h}$ at $60^{\circ} \mathrm{C}$. The outer skins of the dried corn stems were separated manually. The corn stalk fiber appeared light white in color and was directly converted into powder.

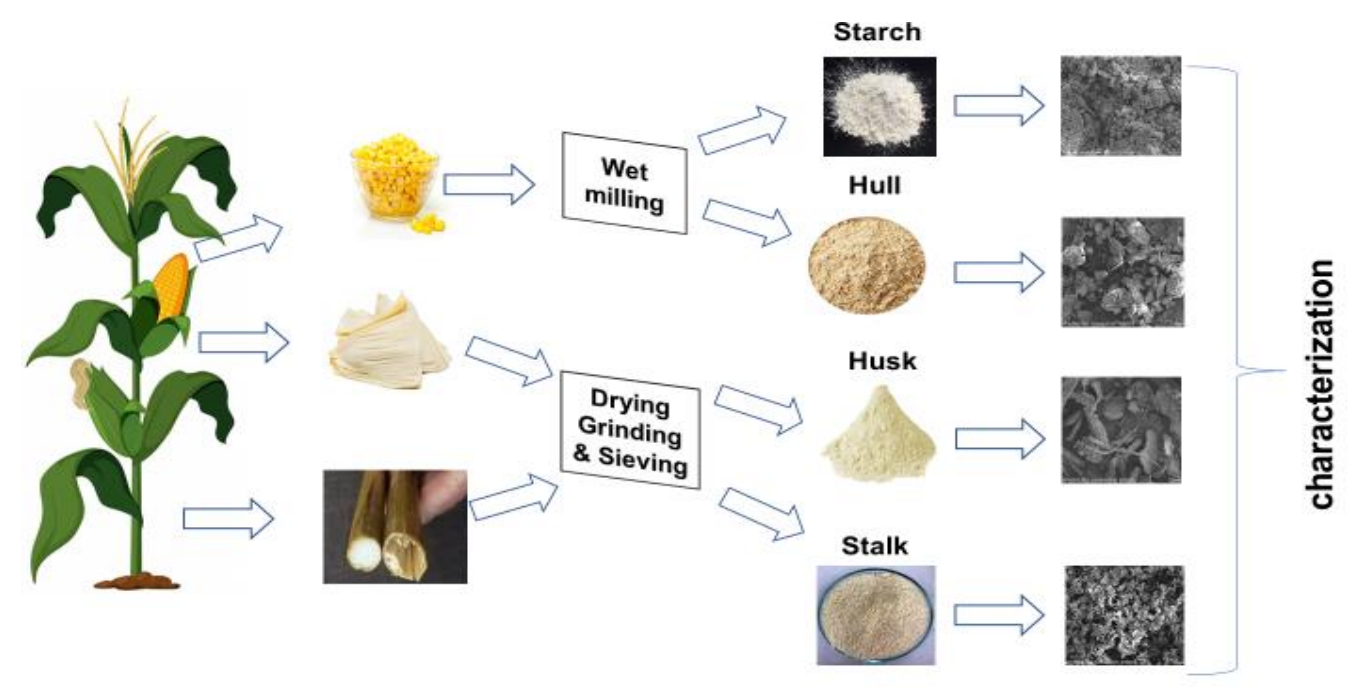

Fig. 1. Extraction and preparation of corn biomass

\section{Chemical Composition}

The chemical composition of the corn samples was measured according to published methods (Razali et al. 2015; Alzorqi et al. 2017). These methods were employed to examine on dry matter the percentages of cellulose, hemicellulose, lignin, and ash of corn fibers. The amylose and amylopectin contents of starch were obtained (James 2013).

\section{Physical Properties}

Density $(\rho)$

A gas pycnometer AccuPyc II 1340 (Micromeritics Instrument Corp., Norcross, USA) was used to obtain the density and volume of known weight powder samples. Helium gas was used as a replacing fluid to measure volume because it has the ability to penetrate and expand through the pores into a chamber containing the sample. Density $(\rho)$ is defined as the ratio of mass $m(\mathrm{~g})$ to volume $v\left(\mathrm{~m}^{3}\right)$ of material, as expressed by Eq. 1 .

$$
\rho\left(\mathrm{g} / \mathrm{m}^{3}\right)=m / v
$$

\section{Moisture content (MC)}

The moisture content of the material is defined as the amount of the water that could be removed from the material without changing the chemical composition for the main weight of the material (Jindal and Siebenmorgen 1987). The powder samples were weighed 
individually and then kept on an oven for $24 \mathrm{~h}$ at $110^{\circ} \mathrm{C}$. The weight differences before $\left(w_{1}\right)$ and after $\left(w_{2}\right)$ drying were used to obtain the $M C$ for each sample indicated by percentage or gram/100 $\mathrm{g}$ as shown in Eq. 2.

$$
\operatorname{MC}(\%)=\left(\left(w_{1}-w_{2}\right) / w_{1}\right) \times 100
$$

\section{Water-holding capacity (WHC)}

Water-holding capacity of a substance is expressed by the ability of the material to hold over water and is indicated by the quantity of water seized by $1 \mathrm{~g}$ of the dehydrated material. The water-holding capacity of the maize samples was measured by a similar method explained by Kirwan et al. (1974) with insignificant modifications. A powder sample $(3 \mathrm{~g})$ in a pre-weighed centrifugal tube $\left(M_{\text {initial }}\right)$ was submerged in $25 \mathrm{~mL}$ of distilled water. After centrifuging at $3000 \mathrm{rpm}$ for 25 min the supernatant was disposed, and the residue was dehydrated in an air circulation oven at $50{ }^{\circ} \mathrm{C}$ for $30 \mathrm{~min}$ and weighed again $\left(M_{\text {final }}\right)$. The test was repeated several times until the tested specimen reached a constant mass. Hence, the $W H C$ percentage was obtained from the average of several measurements according to Eq. 3.

$$
W H C(\%)=\left(\left(M_{\text {final }}-M_{\text {initial }}\right) / M_{\text {initial }}\right) \times 100
$$

\section{Particle size distribution (PSD)}

A Mastersizer 2000 E Ver. 5.52 (Malvern Instruments Ltd., Worcestershire, UK) was used to find out the PSD for the samples via a built in Q-space powder feeder. The particle size for tested samples was examined through a $1000 \mu \mathrm{m}$ sieve prior to distribution analysis.

\section{Thermal Gravity Analyzer (TGA)}

A thermogravimeter analyzer (Q500 V20.13 Build 39, Bellingham, USA) was used to record the specimens' thermal properties. Samples with mass ranging 5 to $10 \mathrm{mg}$ were placed in platinum crucibles and exposed to a temperature varied from room temperature to $450{ }^{\circ} \mathrm{C}$ at a rate of $10^{\circ} \mathrm{C} / \mathrm{min}^{-1}$ and under a nitrogen atmosphere. TGA measures the mass loss over time as a function of temperature.

\section{Morphological and Structural Properties}

Scanning electron microscopy (SEM)

A scanning electron microscope (Hitachi S-3400N, Nara, Japan) was employed to study the surface morphology of the samples. Before the test, the sample was soaked in nitrogen liquid and covered by a golden layer. A $20 \mathrm{kV}$ voltage was applied through a high vacuum to generate a beam of electrons. The applied electrons interacted with the sample atoms creating signals containing information about surface topography and producing images with high resolution.

\section{Fourier transform infrared spectroscopy (FT-IR)}

An infrared spectrometer (Bruker vector 22, Lancashire, UK) was used to obtain the FT-IR spectrum of samples at a frequency over a broad spectral range of 4000 to $400 \mathrm{~cm}^{-1}$ with a spectral resolution of $4 \mathrm{~cm}^{-1}$. The tested samples preparation was conducted via $\mathrm{KBr}$ pressed-disc technique. Using 16 scans per specimen.

$X$-ray diffraction $(X R D)$ 
The XRD analysis was performed using a 2500 X-ray diffractometer (Rigaku, Tokyo, Japan) with a scattering speed of $0.02(\theta) \mathrm{s}^{-1}$ within an angular range from $5^{\circ}$ to $60^{\circ}$ $(2 \theta)$. The operating voltage and current were set to $40 \mathrm{kV}$ and $35 \mathrm{~mA}$, respectively.

\section{RESULTS AND DISCUSSION}

\section{Chemical Composition}

Table 1 reveals the chemical composition of corn starch. The comparative analysis of composition indicated that corn starch is characterized by a relatively high concentration of polysaccharides, (amylopectin and amylose), while the amounts of extractives, such as crude fats, protein, and ash, were quite low. This formulation is consistent with the standard chemical structure of the native starch as mentioned in the previous report (Lu et al. 2009). The amylose content, the main compound of native starches, was $24.6 \mathrm{~g} / 100 \mathrm{~g}$. This amount is roughly equivalent to $25 \mathrm{~g} / 100 \mathrm{~g}$ obtained in an earlier study by Chinnaswamy and Hanna (1988). Also, this amount was found within the normal range (14\% to 29\%) of the amylose content of all native plant starch (Bertoft 2017).

Table 1. Chemical Composition and Physical Properties of Corn Starch

\begin{tabular}{|c|c|c|}
\hline Content & Amount & Units \\
\hline Amylose & 24.64 & $\mathrm{~g} / 100 \mathrm{~g}$ \\
\hline Amylopectin & 75.36 & $\mathrm{~g} / 100 \mathrm{~g}$ \\
\hline Crude fats & 7.13 & $\mathrm{~g} / 100 \mathrm{~g}$ \\
\hline Crude proteins & 7.70 & $\mathrm{~g} / 100 \mathrm{~g}$ \\
\hline Ash & 0.62 & $\mathrm{~g} / 100 \mathrm{~g}$ \\
\hline Phosphor & 0.09 & $\%$ \\
\hline Moisture content & 10.45 & $\%$ \\
\hline Density & 1.4029 & $\mathrm{~g} / \mathrm{cm}^{3}$ \\
\hline
\end{tabular}

Table 2. Comparison of Chemical Composition and Physical Properties of Corn Fibers with Selected Natural Fibers

\begin{tabular}{|c|c|c|c|c|c|c|c|}
\hline Material & $\begin{array}{c}\text { Cellulose } \\
(\%)\end{array}$ & $\begin{array}{c}\text { Hemicellulose } \\
(\%)\end{array}$ & $\begin{array}{c}\text { Lignin } \\
(\%)\end{array}$ & $\begin{array}{c}\text { Ash } \\
(\%)\end{array}$ & $\begin{array}{c}\text { Moisture } \\
(\%)\end{array}$ & $\begin{array}{c}\text { Density } \\
\left(\mathbf{g} / \mathbf{c m}^{3}\right)\end{array}$ & Reference \\
\hline Hull & 15.30 & 40.4 & 2.87 & 0.88 & 8.59 & 1.3231 & $\begin{array}{c}\text { Current } \\
\text { study }\end{array}$ \\
\hline Husk & 45.7 & 35.8 & 4.03 & 0.36 & 7.81 & 1.4913 & $\begin{array}{c}\text { Current } \\
\text { study }\end{array}$ \\
\hline Stalk & 10.8 & 60.3 & 1.98 & 1.97 & 11.1 & 1.4164 & $\begin{array}{c}\text { Current } \\
\text { study }\end{array}$ \\
\hline Juta & 61 to 71.5 & 13.6 to 20.4 & $\begin{array}{c}12 \text { to } \\
13\end{array}$ & $\begin{array}{c}0.5 \\
\text { to } 2\end{array}$ & 12.6 & $\begin{array}{c}1.3 \text { to } \\
1.46\end{array}$ & $\begin{array}{c}\text { (Mohanty et } \\
\text { al. 2001; Li } \\
\text { et al. 2007) }\end{array}$ \\
\hline Hemp & 57 & 14 & 3.7 & 0.8 & 10.8 & 1.48 & $\begin{array}{c}\text { (Mohanty et } \\
\text { al. 2001; } \\
\text { Razali et al. } \\
\text { 2015) }\end{array}$ \\
\hline Sisal & 67 & 10 & 8 & 0.6 & 11 & 1.33 & $\begin{array}{c}\text { (Mohanty et } \\
\text { al. 2001) }\end{array}$ \\
\hline
\end{tabular}


Table 2 displays the chemical composition of maize fibers with a comparison to selected natural fibers. The natural fibers are composed primarily of carbohydrate polymers (cellulose and hemicellulose), aromatic polymers (lignin), and ash. Typically, cellulose acts as a primary constituent for fiber structure and plant strength (Chen 2014). Of the three fibers, corn husk contained the highest concentration of cellulose at $45.7 \%$. This amount was slightly higher than the $43 \%$ previously discovered by Youssef et al. (2015). Corn hull cellulose content from the current study was to some extent lower than the $16 \%$ cellulose content detected by Sugawara et al. (1994). The lignin, which is responsible for flexibility and stiffness of the fiber wall (Varanasi et al. 2013), was found to be present in the corn husk at a more remarkable percentage than in the corn hull and stalk counterparts. A minor concentration of ash was observed in the composition of corn hull and husk fibers, while the ash concentration reached a noticeable amount of about $10.7 \mathrm{~g} / 100 \mathrm{~g}$ on a corn stalk.

\section{Density $(\rho)$ and Moisture Content (MC)}

The density of each specimen was measured among the average of five replicates. As shown in Tables 1 and 2, the density values of corn starch, husk, and stalk were roughly the same at around $1.4 \mathrm{~g} / \mathrm{cm}^{3}$, while the corn hull recorded a lower value at about $1.3 \mathrm{~g} / \mathrm{cm}^{3}$. However, the density values obtained in this study were within the range of various natural fiber densities between 0.81 and $1.450 \mathrm{~g} / \mathrm{m}^{3}$, as indicated in the literature (Rao and Rao 2007). The low-density of biomaterials made it more attractive for manufacturing of biocomposites in comparison with artificial composite materials, such as fiberglass $\left(2.5 \mathrm{~g} / \mathrm{m}^{3}\right)$ (Mendes et al. 2015).

The moisture content of the samples was measured and included in Tables 1 and 2. Cornstalk contained the highest moisture content and reached $11.1 \mathrm{~g} / 100 \mathrm{~g}$. Ashori et al. (2014) attributed that to the presence of the hydroxyl group in cellulose and lignin of corn stalk, whereas corn husk achieved the lowest quantity at $7.81 \mathrm{~g} / 100 \mathrm{~g}$. However, a similar result of corn hull moisture content $(8.59 \mathrm{~g} / 100 \mathrm{~g})$ from this study was detected by Yadav et al. (2007) when the corn hull fiber was extracted through the wet milling process it was found that the moisture content reached $8.41 \mathrm{~g} / 100 \mathrm{~g}$.

\section{Water-Holding Capacity (WHC)}

The ability of the material to absorb water is an important criterion when manufacturing composite materials because it has a great influence on dimensional stability, porosity, tensile strength, and swelling behavior of natural composite materials (Jawaid and Khalil 2011). Based on the data, corn starch, which has a hygroscopic nature, retained the lowest amount of water $(22 \%)$ as compared to the fiber samples, which are characterized by a high hydrophilic nature (Munthoub and Rahman 2011). Cornstalk offered the highest amount of water retention with a value of $93.7 \%$, while corn husk and hull counterparts recorded $78.8 \%$ and $37.4 \%$, respectively; this observation refers to the low amount of cellulose content in the composition of the corn stalk (Ashori et al. 2014). Cellulose decreases the free volume in the fiber intermolecular chain and leads to a reduction of water penetration (Razali et al. 2015). This conclusion is compatible with its chemical composition shown in Table 2.

\section{Particle Size Distribution (PSD)}

The strength of composite materials depends on the efficiency of transferred stress between matrix and fillers. Parameters, such as particle size distribution, particle loading, and particle/matrix interfacial strength, are strongly affected on the composite strength (Fu 
et al. 2008). Thus, the PSD of corn starch is presented in Fig. 2a. The histogram displays that the highest percentage (43\%) of starch particles had sizes of less than $10 \mu \mathrm{m}$, followed by $24 \%$ for the sizes within 10 to $20 \mu \mathrm{m}$. Nonetheless, the vast majority ( $89 \%$ ) of the corn starch particles had sizes less than $40 \mu \mathrm{m}$; such results are identical to the findings of Han et al. (2009). On the other hand, corn husk and stalk exhibited a similar distribution of particle sizes. As revealed in Fig. $2 c$ and d, both fibers showed a large particle size of 200 to $300 \mu \mathrm{m}$ making up $42 \%$ and $39 \%$ of the total particles, respectively. Meanwhile, corn hull had larger particles with $35 \%$ having a particle size of 300 to 400 . This observation is due to the presence of non-removed starch particles attached to hull fiber during the extraction process. Nevertheless, the diminishing size of fiber particles enhances the biodegradability and tensile characteristics of the composite material (Radford 1971; Zhao et al. 2013).
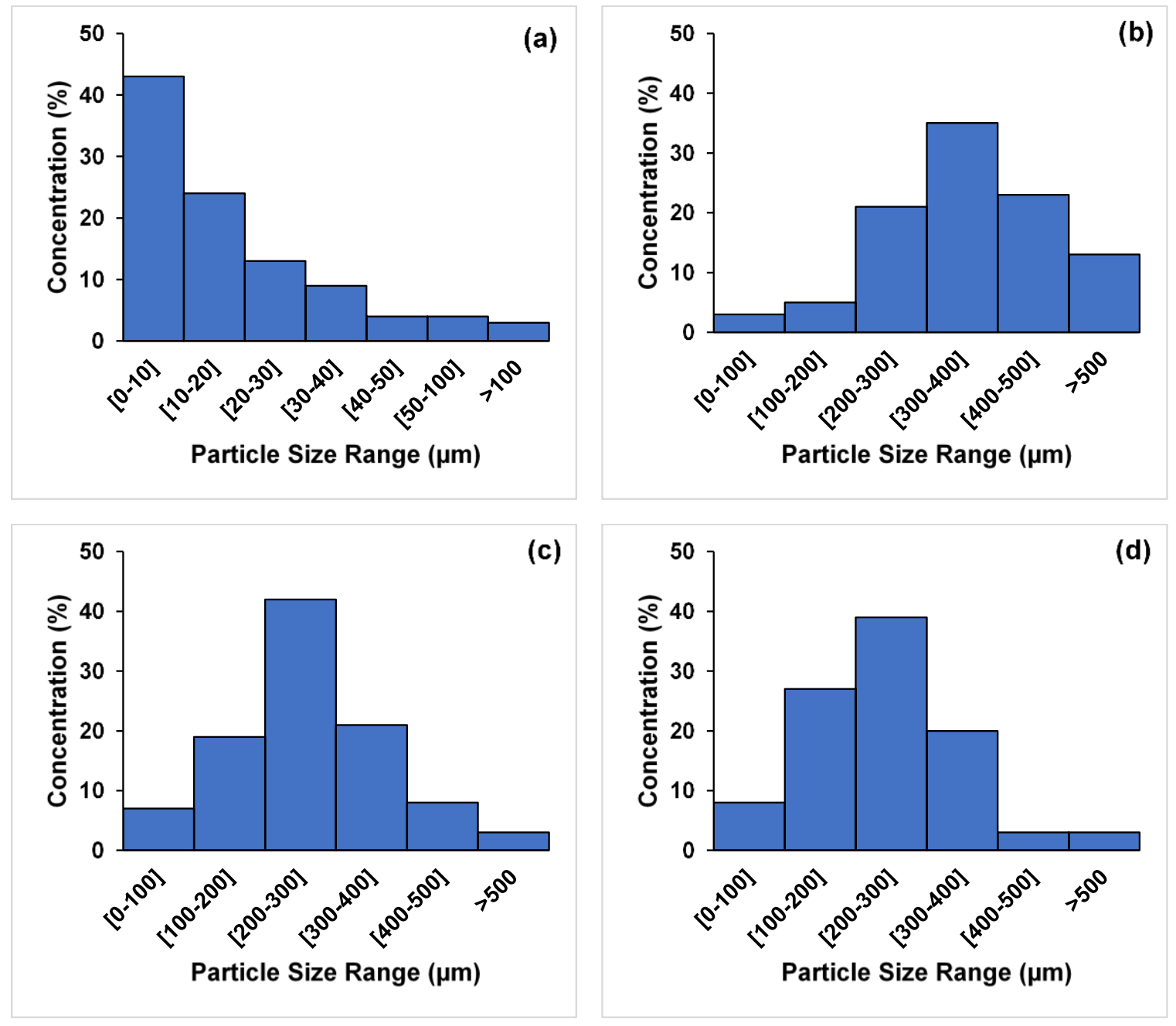

Fig. 2. PSD of a) corn starch, b) corn hull, c) corn husk, and d) corn stalk

\section{Thermal Gravity Analyzer (TGA)}

Thermogravimetric analysis (TGA) and differential thermogravimetry (DTG) are accurate techniques used extensively to investigate the thermal stability and evaluate the weight loss of composite materials (Guinesi et al. 2006). The TGA and DTG curves in Fig. $3 \mathrm{a}$ and $\mathrm{b}$ reveal three distinct phases of weight loss represented in the prominent peaks on 
the DTG curve. The first phase exhibits the loss of weight due to dehydration of water content, the second phase presents the weight loss resulting from the decomposition of the material side chains, and the third phase displays the weight loss due to the decomposition of the main chains of the material (Othman et al. 2011). For the corn starch, the first loss of weight occurred immediately after the dehydration began at a temperature slightly below $100{ }^{\circ} \mathrm{C}$. The weight loss in this phase relies on the moisture content of the starch as a higher moisture content results in higher weight loss. The second phase began with decaying of the water-soluble amylopectin at an onset temperature $\left(T_{\mathrm{o}}\right)$ corresponding to $161.2{ }^{\circ} \mathrm{C}$ and continued until $281.1{ }^{\circ} \mathrm{C}$, resulting in $66.3 \%$ weight loss. The highest rate of thermal degradation of corn starch occurred at about $450{ }^{\circ} \mathrm{C}$ leaving $16.2 \%$ residue of ash. These findings were closer to what was previously obtained by other authors (Liu et al. 2009). Regarding corn (hull, husk, and stalk) fibers, the first weight loss occurred approximately at the same temperature for the three samples at slightly above $100{ }^{\circ} \mathrm{C}$, as shown in Fig. 3 . In the second stage, the fiber material degradation took place due to the decomposition of hemicellulose and cellulose. For all different plant fibers, cellulose content begins to deteriorate at a temperature exceeding $300{ }^{\circ} \mathrm{C}$ and dissolves into its components at about $400{ }^{\circ} \mathrm{C}$ (Yang et al. 2007). The corresponding data are shown in Table 3.
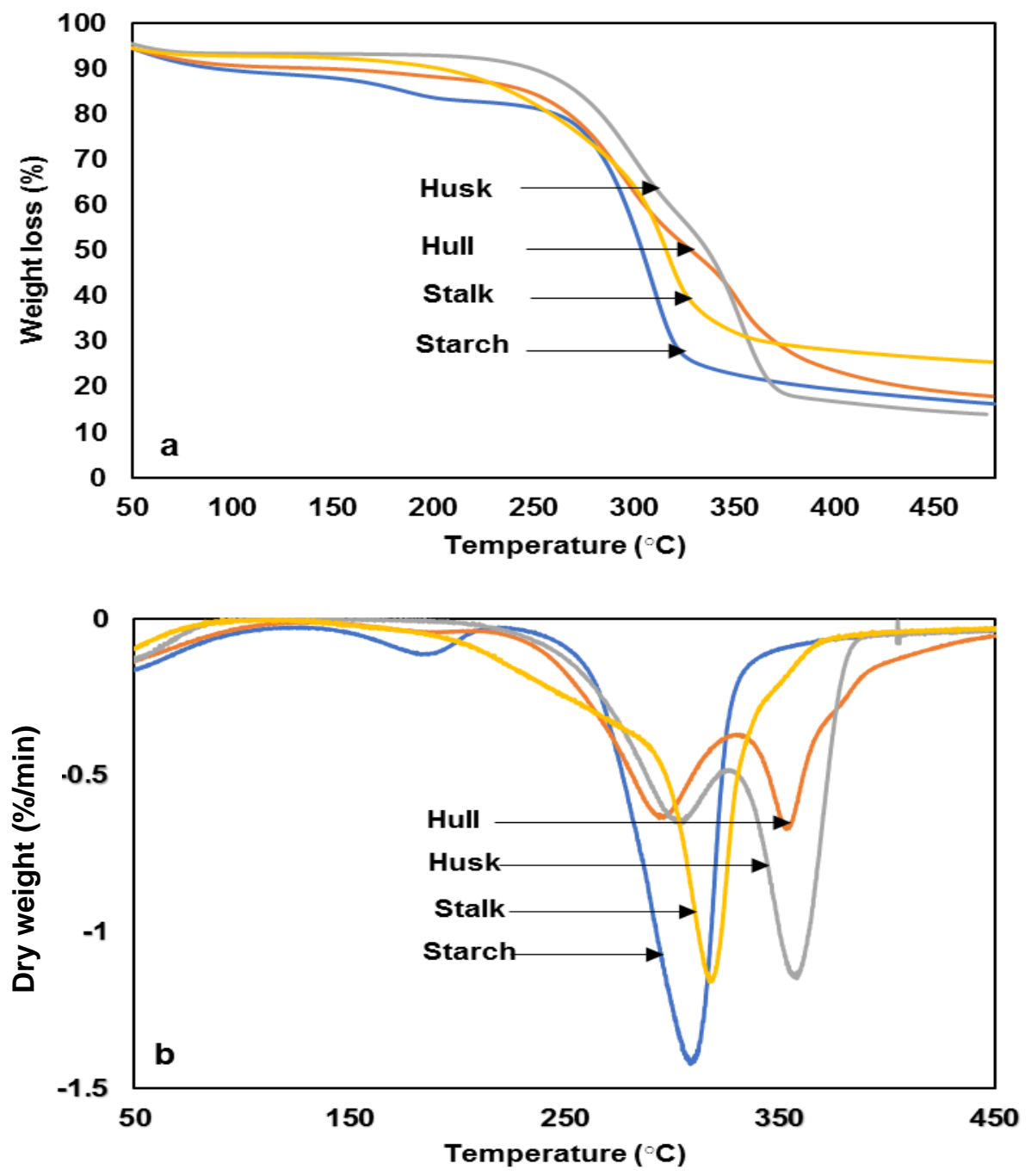

Fig. 3. a) TGA and b) DTG of corn starch, hull, husk, and stalk 
Table 3. Thermal Degradation of Corn Starch, Hull, Husk and Stalk, Comparison with Cassava Biomass

\begin{tabular}{|c|c|c|c|c|l|}
\hline \multirow{2}{*}{ Material } & \multicolumn{3}{|c|}{$\begin{array}{c}\text { Degradation Temperatures } \\
\left({ }^{\circ} \mathbf{C}\right)\end{array}$} & $\begin{array}{l}\text { Mass } \\
\text { Residue }(\%) \\
\text { above } \mathbf{4 0 0}{ }^{\circ} \mathbf{C}\end{array}$ & $\begin{array}{l}\text { DTG Peak } \\
\text { Temperature } \\
\left({ }^{\circ} \mathbf{C}\right)\end{array}$ \\
\cline { 2 - 6 } & $T_{\text {onset }}$ & $T_{25 \%}$ & $T_{50 \%}$ & 16.24 & 310 \\
\hline Starch & 161.20 & 281.08 & 303.79 & 17.87 & 352 \\
\hline Hull & 258.94 & 278.58 & 343.38 & 13.86 & 350 \\
\hline Husk & 264.27 & 289.57 & 340.19 & 25.42 & 318 \\
\hline Stalk & 274.94 & 278.74 & 315.35 & & \\
\hline
\end{tabular}

The onset decomposition temperatures achieved in this study suggest that the use of corn fibers as fillers for polymer composites production is possible because the majority of polymer composites are processed at above of $180{ }^{\circ} \mathrm{C}$ (Mendes et al. 2015). In the final stage, the highest rate of thermal degradation occurred above $400{ }^{\circ} \mathrm{C}$ as a result of lignin decomposition. However, the results are well in agreement with the thermal decomposition of natural fibers, which begins with the decaying of hemicellulose $\left(200{ }^{\circ} \mathrm{C}\right.$ to $\left.260{ }^{\circ} \mathrm{C}\right)$, cellulose $\left(240{ }^{\circ} \mathrm{C}\right.$ to $\left.350{ }^{\circ} \mathrm{C}\right)$, and lignin $\left(280{ }^{\circ} \mathrm{C}\right.$ to $\left.500{ }^{\circ} \mathrm{C}\right)$ (Lomelí-Ramírez et al. 2014).
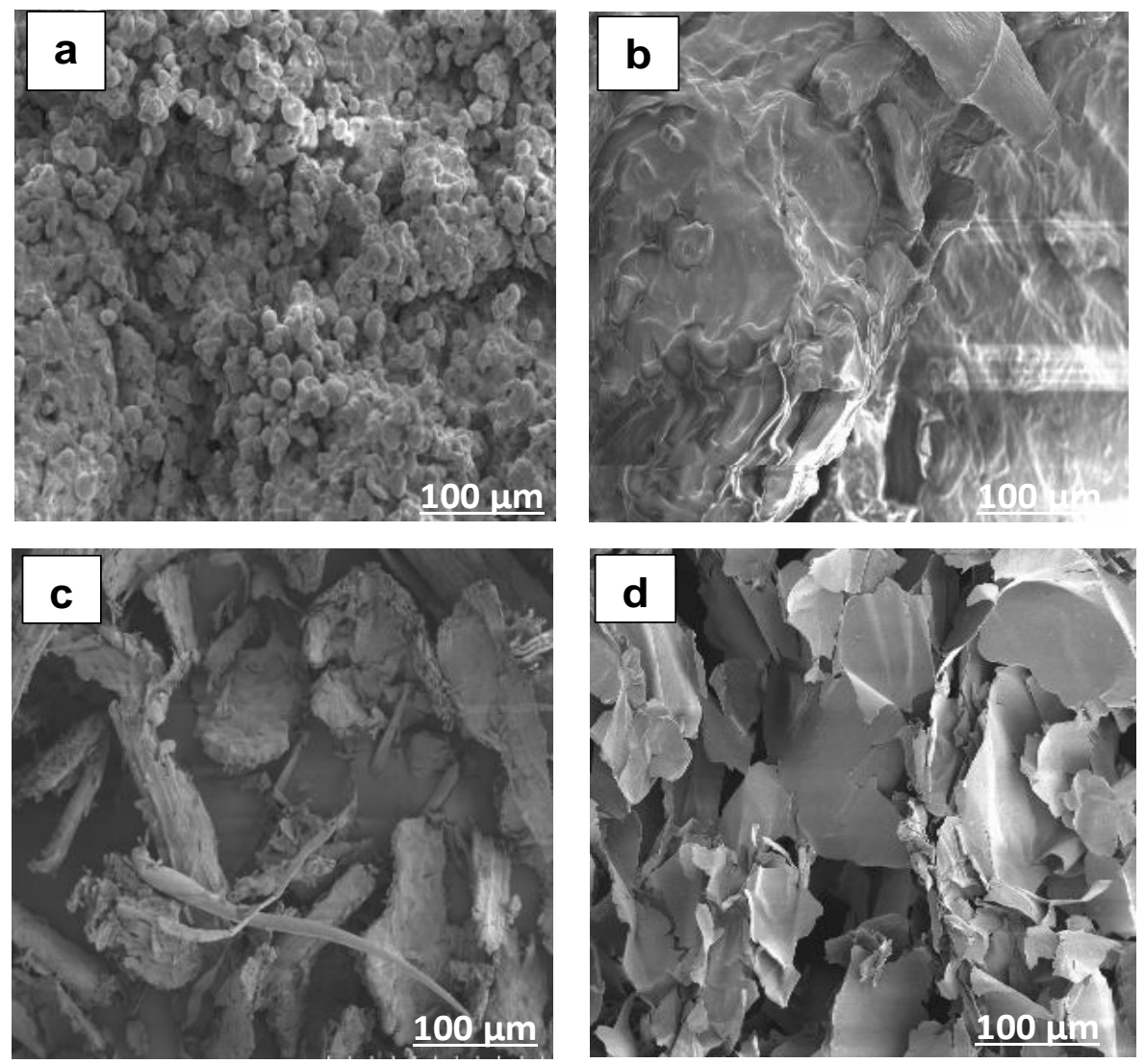

Fig. 4. SEM of a) corn starch, b) hull, c) husk, and d) stalk

\section{Scanning Electron Microscopy}

Figure 4 a shows the surface morphology of corn starch. The remarkable shape of the starch granules was found to be varied from aspherical to polyhedral shapes with solid structure, and most granule sizes were less than $40 \mu \mathrm{m}$. Moreover, the view showed smooth scratched surfaces with slight porosity, which is usually related to the starch genotype as 
well as to extraction and storage conditions (Leach and Schoch 1961). The surface fracture of corn hull as displayed in Fig. 4b reveals a fiber with starch particles covering the surfaces. The observed surface of the hull granules was found to be smooth and relatively cohesive, which could be ascribed to the remains of corn starch molecules from the detaching process. Also, the corn hull visualization shows wrinkled spongy surfaces that may lead to weak interfacial adhesion between matrix and filler. Therefore, hull fiber could not afford an effective stress transfer from the matrix (Tabari et al. 2011). Figure 4c illustrates the morphological structure of corn husk. The images exhibited husk particles with a nonuniform cross section and irregular surfaces. Also, some impurities were noticed on the structure, which is undesirable for composites integrity. Moreover, corn husk appeared to have rough surfaces with some pores that could be allow for better adhesion during the mixing process. This description is well aligned with the findings reported by Mendes et al. (2015). The surface fracture of the corn stalk is visualized in Fig. 4d. The typical view showed a fibrous and porous structure with an irregular cross section. Also, relatively smooth surfaces with some defects were detected, which may influence negatively on cohesion bonds between matrices and fillers. Similar results were observed in the prior study performed by Kaliyan and Morey (2010).

\section{Fourier Transform Infrared Spectroscopy}

The interpretation of the leading bands of corn starch was carried out by dividing the FT-IR spectra curve into four main zones. The first zone was at wavenumbers below $800 \mathrm{~cm}^{-1}$, the second zone was at wavenumbers between 800 and $1500 \mathrm{~cm}^{-1}$, the third zone was within the $\mathrm{C}-\mathrm{H}$ stretch region from 2800 to $3000 \mathrm{~cm}^{-1}$, and the last zone was the O-H stretch area above $3000 \mathrm{~cm}^{-1}$ (Kizil et al. 2002). Consequently, the FT-IR spectrum of corn starch as shown in Fig. 5 revealed an oscillatory behavior in the region below $800 \mathrm{~cm}^{-1}$. This behavior is related to vibrations of glucose pyranose units (Kizil et al. 2002). In the second region, starch appeared to have complex spectra with remarkable overlapping originating from $\mathrm{C}-\mathrm{O}$ vibrational stretching of the monomer glucose unit. Also, the presence of the $\mathrm{C}-\mathrm{O}-\mathrm{H}$ bending mode caused the appearance of the band at $1076 \mathrm{~cm}^{-1}$, whereas the coupling modes of C-O and C-C stretching showed up in the peak at $1149 \mathrm{~cm}^{-1}$. However, the infrared wavenumbers at the peak at $1335 \mathrm{~cm}^{-1}$ were attributed to $\mathrm{CH}_{2}$ bending modes (Cael et al. 1975). Additionally, the vibrations of water fragments in the amorphous region of starch granules resulted in the emergence of broad infrared bands at peaks at $1640 \mathrm{~cm}^{-1}$ and $1709 \mathrm{~cm}^{-1}$ (Santha et al. 1990). In the third area between 2800 and $3000 \mathrm{~cm}^{-1}$, and the presence of the C-H stretching vibration generated the peaks at $2853 \mathrm{~cm}^{-1}$ and $2923 \mathrm{~cm}^{-1}$. Finally, the fourth vibration region of the $\mathrm{O}-\mathrm{H}$ stretch hydroxyl groups led to the creation of the last band at $3285 \mathrm{~cm}^{-1}$ (Pi-Xin et al. 2009).

The FT-IR analysis of corn husk and stalk fiber is displayed in Fig. 5. It can be seen that both fibers exhibited roughly the same trends. The main differences between husk and stalk were the position and width of the bands at $1635 \mathrm{~cm}^{-1}, 2917 \mathrm{~cm}^{-1}$, and $3333 \mathrm{~cm}^{-1}$ for the corn husk had shifted to $1604 \mathrm{~cm}^{-1}, 2897 \mathrm{~cm}^{-1}$, and $3339 \mathrm{~cm}^{-1}$ for the corn stalk counterpart. These differences are related to the variances in the chemical composition, particularly cellulose, hemicellulose, and crude protein contents. Furthermore, both husk and stalk in the aromatic region, which correlates to lignin (Ali et al. 2001), recorded the same peaks at $1159 \mathrm{~cm}^{-1}, 1370 \mathrm{~cm}^{-1}$, and $1515 \mathrm{~cm}^{-1}$. Likewise, both husk and stalk fibers stretched at the peak at $897 \mathrm{~cm}^{-1}$ which was assigned to the $\mathrm{C}-\mathrm{O}-\mathrm{C}$ stretching of glycosidic linkages in cellulose (Jonoobi et al. 2009; Y1lmaz 2013). However, almost the same peaks were observed by Husseien et al. (2009) who recorded peaks at $3415 \mathrm{~cm}^{-1}, 1638 \mathrm{~cm}^{-1}$, and 
$900 \mathrm{~cm}^{-1}$ for corn stalk. Similarly, Y1lmaz (2013) found peaks at $3400 \mathrm{~cm}^{-1}, 2923 \mathrm{~cm}^{-1}$, and $897 \mathrm{~cm}^{-1}$ for corn husk. Regarding corn hull, it was observed that corn hull offered additional sharp bands at peaks at $2921 \mathrm{~cm}^{-1}$ and $2852 \mathrm{~cm}^{-1}$. The prominence of these peaks was attributed to the presence of starch residues attached to hull fiber from the extraction process.

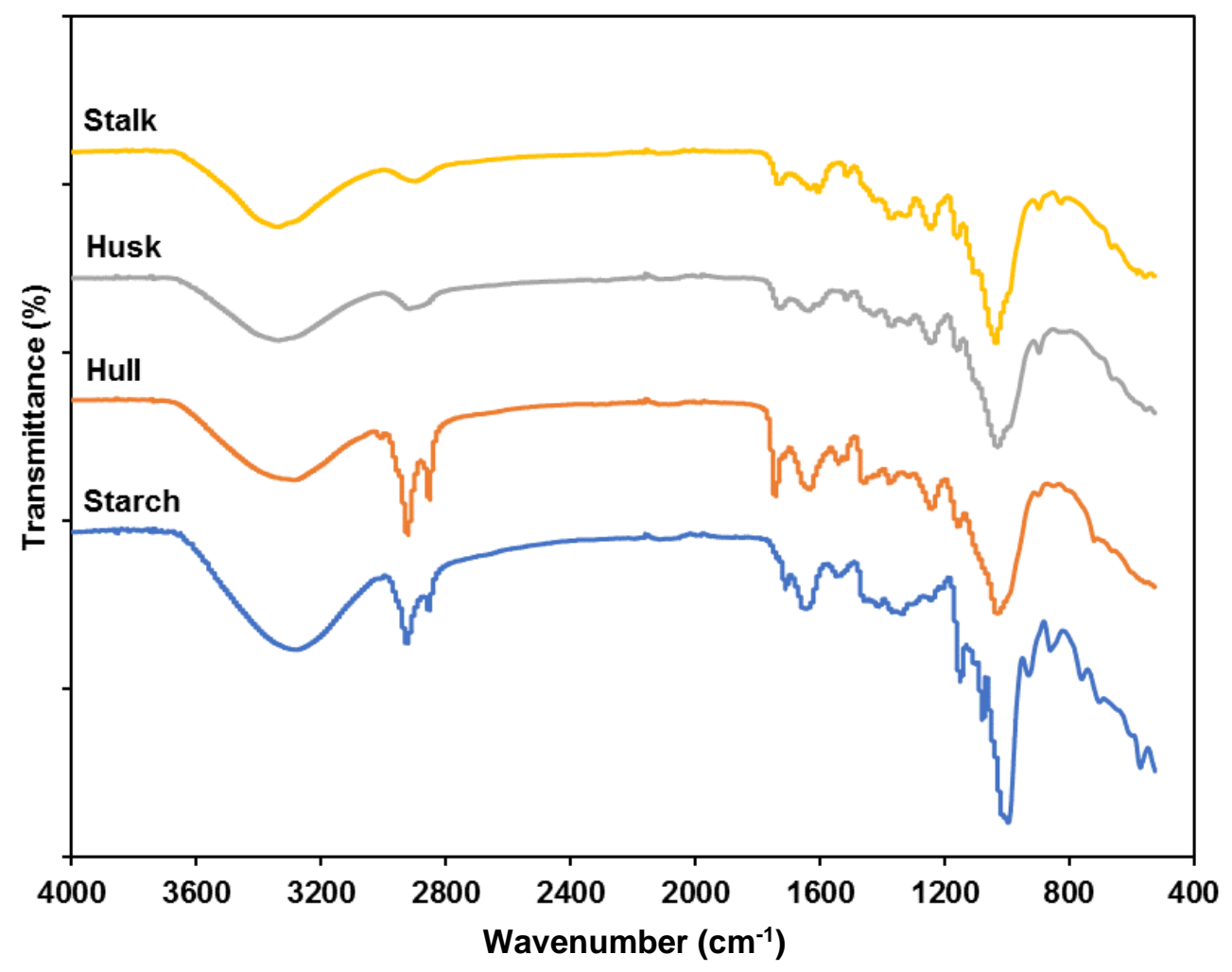

Fig. 5. FT-IR spectroscopy of corn starch, hull, husk, and stalk

\section{X-ray Diffraction}

The XRD structure of native corn starch as illustrated in Fig. 6 shows five $2 \theta$ diffraction angles focused at peaks at $15.14^{\circ}, 17.4^{\circ}, 18.6^{\circ}, 20.11^{\circ}$, and $22.8^{\circ}$. These peaks represent the A-type starch semi-crystallinity structure, which is the typical pattern of all cereal starches (Shamai et al. 2003). The peaks obtained from the current study are effectively compatible with those introduced by Paraginski et al. (2014) for native corn starch with the peaks being found at $15^{\circ}, 17^{\circ}, 18^{\circ}, 20^{\circ}$, and $23^{\circ}$. These are also mostly comparable to those revealed by Koo et al. (2010) at peaks at $15.02^{\circ}, 17.18^{\circ}$, and $23.73^{\circ}$.

The corresponding spectrum of corn hull fiber peaks of crystalline and amorphous regions appeared at the following $2 \theta$ angles; a minor peak at $18^{\circ}$ and a high peak at close to $20^{\circ}$. These peaks are related to the remains of corn starch in the hull fiber. However, the morphological properties of maize fiber composites can be attributed to the distinctive diffraction behavior of corn hull to disordered regions and scattering of crystallinity to this material (Sisson 1938). As for the XRD patterns of corn husk and stalk, the results showed that the main peaks for corn husk and corn stalk were located at positions $21.75^{\circ}$ and $21.43^{\circ}$, respectively. Likewise, both fibers revealed a minor broad peak at $2 \theta$ equivalent to $15.88^{\circ}$ for corn husk and at $15.76^{\circ}$ for the corn stalk counterpart. These observations are similar to those of the corn stalk obtained by Zhao et al. (2013) and those of the corn husk in the study of Mendes et al. (2015). 


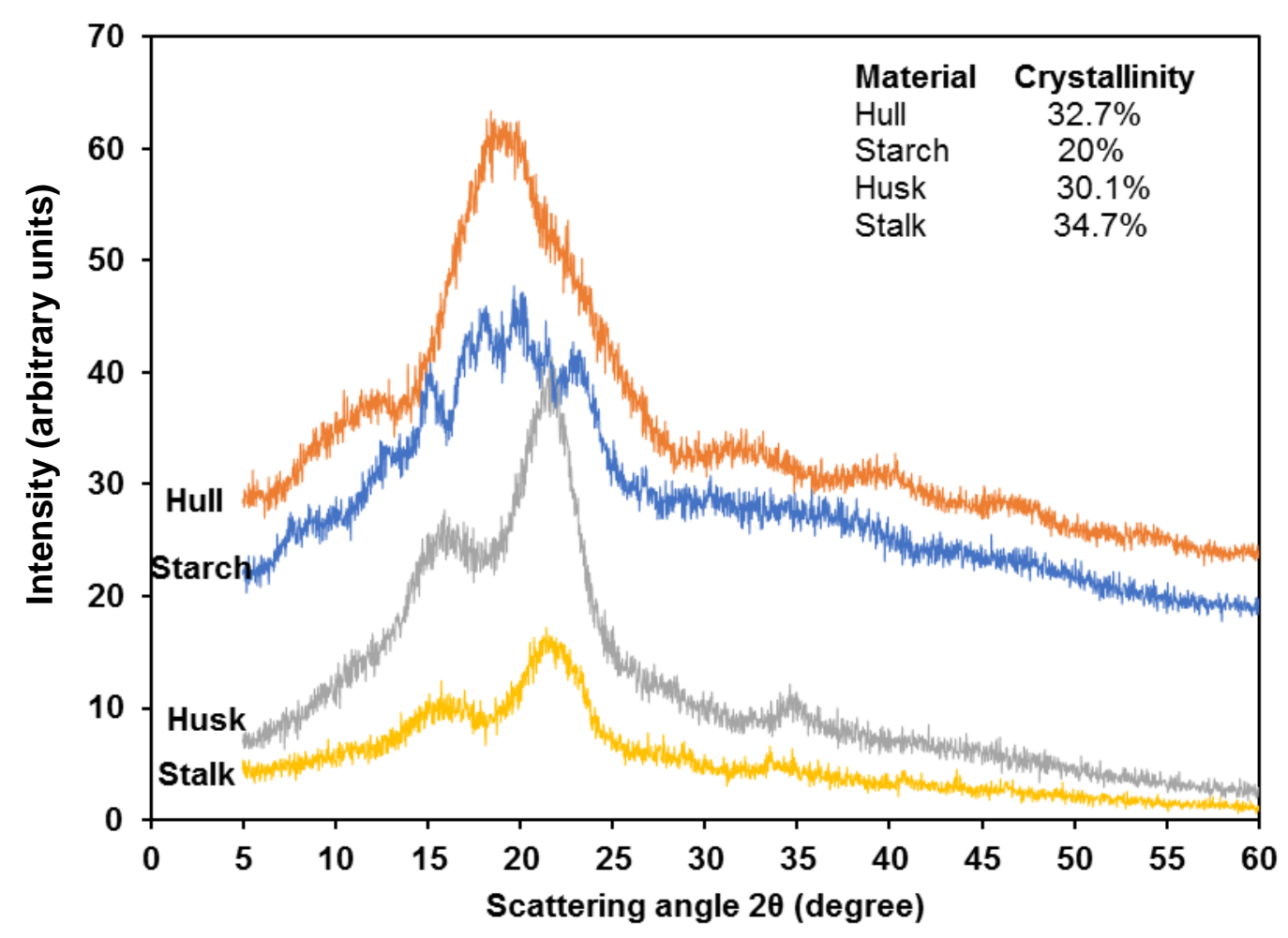

Fig. 6. X-ray diffractogram of corn starch, hull, husk, and stalk

\section{CONCLUSIONS}

1. Three lignocellulosic fibers (hull, husk, and stalk) along with thermoplastic starch polymer have been isolated and characterized with the aim of obtaining biomasses for biomaterial applications.

2. The highest concentrations of cellulose and lignin were found in corn husk. The largest amount of hemicellulose was obtained in corn stalk fiber.

3. Thermal results revealed that corn starch degraded at $161.2{ }^{\circ} \mathrm{C}$, while hull, husk, and stalk fibers began decomposing above $260{ }^{\circ} \mathrm{C}$. That made the use of corn fibers as fillers for polymer composites production possible because the majority of polymer composites are processed at above $180{ }^{\circ} \mathrm{C}$.

4. The morphological analysis exhibited aspherical to polyhedral shapes for corn starch molecules. The husk showed an irregular shape with a coarse surface which could lead to better adhesion, stalk displayed a fibrous surface with little porosity, and hull depicted smooth spongy surfaces.

5. Corn starch and the fiber extracted from corn husk were found to provide the most favorable collection of characteristics in the present research. Thus, they are likely to be used as a sustainable biomass for various applications, especially as an alternative to synthetic plastic uses such bio-films making and packaging. 


\section{ACKNOWLEDGMENTS}

The authors thank Universiti Putra Malaysia and Ministry of Education, Malaysia, for the financial support through the UPM Grant scheme Hi-CoE (6369107).

\section{REFERENCES CITED}

Ali, A., Wani, T. A., Wani, I. A., and Masoodi, F. A. (2016). "Comparative study of the physico-chemical properties of rice and corn starches grown in Indian temperate climate," Journal of the Saudi Society of Agricultural Sciences 15(1), 75-82. DOI: 10.1016/j.jssas.2014.04.002

Ali, M., Emsley, A., Herman, H., and Heywood, R. (2001). "Spectroscopic studies of the ageing of cellulosic paper," Polymer 42(7), 2893-2900. DOI: 10.1016/S00323861(00)00691-1

Alzorqi, I., Sudheer, S., Lu, T.-J., and Manickam, S. (2017). "Ultrasonically extracted $\beta$ d-glucan from artificially cultivated mushroom, characteristic properties and antioxidant activity," Ultrasonics Sonochemistry 35, 531-540. DOI: 10.1016/j.ultsonch.2016.04.017

Ashori, A., Nourbakhsh, A., and Tabrizi, A. K. (2014). "Thermoplastic hybrid composites using bagasse, corn stalk and E-glass fibers: Fabrication and characterization," Polymer-Plastics Technology and Engineering 53(1), 1-8. DOI: 10.1080/03602559.2013.832854

Baranitharan, P., and Mahesh, G. (2014). "Alkali treated maize fibers reinforced with epoxy poly matrix composites," Magnesium 15(30), 150.

Bertoft, E. (2017). "Understanding starch structure: Recent progress," Agronomy 7(3), 56. DOI: 10.3390/agronomy7030056

Brinchi, L., Cotana, F., Fortunati, E., and Kenny, J. (2013). "Production of nanocrystalline cellulose from lignocellulosic biomass: Technology and applications," Carbohydrate Polymers 94(1), 154-169. DOI: 10.1016/j.carbpol.2013.01.033

Cael, J. J., Koenig, J. L., and Blackwell, J. (1975). "Infrared and Raman spectroscopy of carbohydrates. Part VI: Normal coordinate analysis of V-amylose," Biopolymers: Original Research on Biomolecules 14(9), 1885-1903. DOI: 10.1002/bip.1975.360140909

Chen, H. (2014). "Chemical composition and structure of natural lignocellulose," in: Biotechnology of Lignocellulose, Springer, Dordrecht. pp. 25-71.

Chinnaswamy, R., and Hanna, M. (1988). "Relationship between amylose content and extrusion-expansion properties of corn starches," Cereal Chemistry 65(2), 138-143.

Fu, S.-Y., Feng, X.-Q., Lauke, B., and Mai, Y.-W. (2008). "Effects of particle size, particle/matrix interface adhesion and particle loading on mechanical properties of particulate-polymer composites," Composites Part B: Engineering 39(6), 933-961. DOI: 10.1016/j.compositesb.2008.01.002

Guinesi, L. S., da Róz, A. L., Corradini, E., Mattoso, L. H. C., Teixeira, E. d. M., and Curvelo, A. A. d. S. (2006). "Kinetics of thermal degradation applied to starches from different botanical origins by non-isothermal procedures," Thermochimica Acta 447(2), 190-196. DOI: 10.1016/j.tca.2006.06.002

Han, Z., Zeng, X-a., Zhang, B-s., and Yu, S-j. (2009). "Effects of pulsed electric fields (PEF) treatment on the properties of corn starch," Journal of Food Engineering 93(3), 
318-323. DOI: 10.1016/j.jfoodeng.2009.01.040

Husseien, M., Amer, A., El-Maghraby, A., and Hamedallah, N. (2009). “A comprehensive characterization of corn stalk and study of carbonized corn stalk in dye and gas oil sorption," Journal of Analytical and Applied Pyrolysis 86(2), 360-363. DOI: 10.1016/j.jaap.2009.08.003

Ibrahim, M. I. J., Sapuan, S. M., Zainudin, E. S., and Zuhri, M. Y. M. (2019). "Physical, thermal, morphological, and tensile properties of cornstarch-based films as affected by different plasticizers," International Journal of Food Properties 22(1), 925-941. DOI: 10.1080/10942912.2019.1618324

James, C. S. (2013). Analytical Chemistry of Foods, Springer Science \& Business Media, Dordrecht, Netherlands.

Jawaid, M., and Khalil, H. A. (2011). "Cellulosic/synthetic fibre reinforced polymer hybrid composites: A review," Carbohydrate Polymers 86(1), 1-18. DOI: 10.1016/j.carbpol.2011.04.043

Jindal, V., and Siebenmorgen, T. (1987). "Effects of oven drying temperature and drying time on rough rice moisture content determination," Transactions of the ASAE 30(4), 1185-1192. DOI: $10.13031 / 2013.30542$

Jonoobi, M., Harun, J., Mishra, M., and Oksman, K. (2009). "Chemical composition, crystallinity and thermal degradation of bleached and unbleached kenaf bast (Hibiscus cannabinus) pulp and nanofiber," BioResources 4(2), 626-639.

Kaliyan, N., and Morey, R. V. (2010). "Natural binders and solid bridge type binding mechanisms in briquettes and pellets made from corn stover and switchgrass," Bioresource Technology 101(3), 1082-1090. DOI: 10.1016/j.biortech.2009.08.064

Kirwan, W., Smith, A., McConnell, A., Mitchell, W., and Eastwood, M. (1974). "Action of different bran preparations on colonic function," British Medical Journal 4(5938), 187-189. DOI: $10.1136 / \mathrm{bmj} .4 .5938 .187$

Kizil, R., Irudayaraj, J., and Seetharaman, K. (2002). "Characterization of irradiated starches by using FT-Raman and FTIR spectroscopy," Journal of Agricultural and Food Chemistry 50(14), 3912-3918. DOI: 10.1021/jf011652p

Koo, S. H., Lee, K. Y., and Lee, H. G. (2010). "Effect of cross-linking on the physicochemical and physiological properties of corn starch," Food Hydrocolloid 24(6-7), 619-625. DOI: 10.1016/j.foodhyd.2010.02.009

Leach, H. W., and Schoch, T. J. (1961). "Structure of starch granule. II. Action of various amylases on granular starches," Cereal Chemistry 38(1), 34.

Li, X., Tabil, L. G., and Panigrahi, S. (2007). "Chemical treatments of natural fiber for use in natural fiber-reinforced composites: A review," Journal of Polymers and the Environment 15(1), 25-33. DOI: 10.1007/s10924-006-0042-3

Liu, X., Yu, L., Liu, H., Chen, L., and Li, L. (2009). "Thermal decomposition of corn starch with different amylose/amylopectin ratios in open and sealed systems," Cereal Chemistry, 86(4), 383-385. DOI: 10.1094/CCHEM-86-4-0383

Lomelí-Ramírez, M. G., Kestur, S. G., Manríquez-González, R., Iwakiri, S., de Muniz, G. B., and Flores-Sahagun, T. S. (2014). "Bio-composites of cassava starch-green coconut fiber: Part II-Structure and properties," Carbohydrate Polymers 102, 576583. DOI: 10.1016/j.carbpol.2013.11.020

Lu, Z.-H., Sasaki, T., Li, Y.-Y., Yoshihashi, T., Li, L.-T., and Kohyama, K. (2009). "Effect of amylose content and rice type on dynamic viscoelasticity of a composite rice starch gel," Food Hydrocolloids 23(7), 1712-1719. DOI:

10.1016/j.foodhyd.2009.01.009 
McAloon, A., Taylor, F., Yee, W., Ibsen, K., and Wooley, R. (2000). Determining the Cost of Producing Ethanol from Corn Starch and Lignocellulosic Feedstocks (NREL/TP-580-28893), National Renewable Energy Lab, Golden, CO, USA.

Mendes, C., Adnet, F., Leite, M., Furtado, C. G., and Sousa, A. (2015). "Chemical, physical, mechanical, thermal and morphological characterization of corn husk residue," Cellulose Chemistry and Technology 49(9-10), 727-735.

Mendes, J., Paschoalin, R., Carmona, V., Neto, A. R. S., Marques, A., Marconcini, J., Mattoso, L. H. C., Medeiros, E. C., and Oliveira, J. (2016). "Biodegradable polymer blends based on corn starch and thermoplastic chitosan processed by extrusion," Carbohydrate Polymers 137, 452-458. DOI: 10.1016/j.carbpol.2015.10.093

Mohanty, A., Misra, M., and Drzal, L. T. (2001). "Surface modifications of natural fibers and performance of the resulting biocomposites: An overview," Composite Interfaces 8(5), 313-343. DOI: 10.1163/156855401753255422

Mori, S., Tenazoa, C., Candiotti, S., Flores, E., and Charca, S. (2018). "Assessment of ichu fibers extraction and their use as reinforcement in composite materials," Journal of Natural Fibers 1-16. DOI: 10.1080/15440478.2018.1527271

Munthoub, D. I., and Rahman, W. (2011). "Tensile and water absorption properties of biodegradable composites derived from cassava skin/polyvinyl alcohol with glycerol as plasticizer," Sains Malaysiana 40(7), 713-718.

Othman, N., Azahari, N. A., and Ismail, H. (2011). "Thermal properties of polyvinyl alcohol (PVOH)/corn starch blend film," Malaysian Polymer Journal 6(6), 147-154. DOI:

Paraginski, R. T., Vanier, N. L., Moomand, K., de Oliveira, M., da Rosa Zavareze, E., e Silva, R. M., Ferreira C. D., and Elias, M. C. (2014). "Characteristics of starch isolated from maize as a function of grain storage temperature," Carbohydrate Polymers 102, 88-94. DOI: 10.1016/j.carbpol.2013.11.019

Pi-Xin, W., Xiu-Li, W., Xue, D-h., Xu, K., Tan, Y., Du, X-b., and Li, W-b. (2009). "Preparation and characterization of cationic corn starch with a high degree of substitution in dioxane-THF-water media," Carbohydrate Research 344(7), 851-855. DOI: 10.1016/j.carres.2009.02.023

Radford, K. (1971). "The mechanical properties of an epoxy resin with a second phase dispersion," Journal of Materials Science 6(10), 1286-1291.

Rao, K. M. M., and Rao, K. M. (2007). "Extraction and tensile properties of natural fibers: Vakka, date and bamboo," Composite Structures 77(3), 288-295. DOI: 10.1016/j.compstruct.2005.07.023

Razali, N., Salit, M. S., Jawaid, M., Ishak, M. R., and Lazim, Y. (2015). “A study on chemical composition, physical, tensile, morphological, and thermal properties of roselle fibre: Effect of fibre maturity," BioResources 10(1), 1803-1824.

Sandhu, K. S., Singh, N., and Kaur, M. (2004). "Characteristics of the different corn types and their grain fractions: Physicochemical, thermal, morphological, and rheological properties of starches," Journal of Food Engineering 64(1), 119-127. DOI: org/10.1016/j.jfoodeng.2003.09.023

Santha, N., Sudha, K., Vijayakumari, K., Nayar, V., and Moorthy, S. (1990). "Raman and infrared spectra of starch samples of sweet potato and cassava," Journal of Chemical Sciences 102(5), 705-712. DOI: 10.1007/BF03040801

Sari, N. H., Wardana, I., Irawan, Y. S., and Siswanto, E. (2016). "Physical and acoustical properties of corn husk fiber panels," Advances in Acoustics and Vibration 2016.

DOI: $10.1155 / 2016 / 5971814$ 
Shamai, K., Bianco-Peled, H., and Shimoni, E. (2003). "Polymorphism of resistant starch type III," Carbohydrate Polymers 54(3), 363-369. DOI: 10.1016/S01448617(03)00192-9

Singh, R., Ram, L., and Srivastava, R. (2016). “A journey of hybrids in maize: An overview," Indian Research Journal of Extension Education 12(2), 340-344.

Sisson, W. A. (1938). "X-ray diffraction behaviour of cellulose derivatives," Industrial \& Engineering Chemistry 30(5), 530-537. DOI: 10.1021/ie50341a012

Sugawara, M., Suzuki, T., Totsuka, A., Takeuchi, M., and Ueki, K. (1994). “Composition of corn hull dietary fiber," Starch-Stärke 46(9), 335-337. DOI: 10.1002/star.19940460904

Tabari, H. Z., Nourbakhsh, A., and Ashori, A. (2011). "Effects of nanoclay and coupling agent on the physico-mechanical, morphological, and thermal properties of wood flour/polypropylene composites," Polymer Engineering \& Science 51(2), 272-277. DOI: $10.1002 /$ pen. 21823

Varanasi, P., Singh, P., Auer, M., Adams, P. D., Simmons, B. A., and Singh, S. (2013). "Survey of renewable chemicals produced from lignocellulosic biomass during ionic liquid pretreatment," Biotechnology for Biofuels 6(1), 14. DOI: 10.1186/1754-6834-614

Weatherwax, P. (1950). "The history of corn," The Scientific Monthly 71(1), 50-60.

Yadav, M. P., Johnston, D. B., Hotchkiss Jr, A. T., and Hicks, K. B. (2007). "Corn fiber gum: A potential gum arabic replacer for beverage flavor emulsification," Food Hydrocolloids 21(7), 1022-1030. DOI: 10.1016/j.foodhyd.2006.07.009

Yang, H., Yan, R., Chen, H., Lee, D. H., and Zheng, C. (2007). "Characteristics of hemicellulose, cellulose and lignin pyrolysis," Fuel 86(12-13), 1781-1788. DOI: 10.1016/j.fuel.2006.12.013

Y1lmaz, N. D. (2013). "Effects of enzymatic treatments on the mechanical properties of corn husk fibers," Journal of the Textile Institute 104(4), 396-406. DOI: 10.1080/00405000.2012.736707

Youssef, A. M., El-Gendy, A., and Kamel, S. (2015). "Evaluation of corn husk fibers reinforced recycled low density polyethylene composites," Materials Chemistry and Physics 152, 26-33. DOI: 10.1016/j.matchemphys.2014.12.004

Zhao, X., Chen, J., Chen, F., Wang, X., Zhu, Q., and Ao, Q. (2013). "Surface characterization of corn stalk superfine powder studied by FTIR and XRD," Colloids and Surfaces B: Biointerfaces 104, 207-212. DOI: 10.1016/j.colsurfb.2012.12.003

Zobel, H. (1988). "Starch crystal transformations and their industrial importance. StarchStärke 40(1), 1-7. DOI: 10.1002/star.19880400102

Article submitted: March 27, 2019; Peer review completed: May 25, 2019; Revised version received: June 13, 2019; Accepted: June 21, 2019; Published: June 26, 2019.

DOI: 10.15376/biores.14.3.6485-6500 